\title{
Estimation of Indonesia's Energy Demand to 2030 and Alternatives Scenario to Reduce Oil Dependence
}

\author{
Dwi Atty Mardiana ${ }^{1 *}$, RS. Trijana Kartoatmodjo ${ }^{2}$, Sugiatmo Kasmungin ${ }^{3}$ \\ ${ }^{1,2,3}$ Faculty of Earth Technology and Energy, Trisakti University, Indonesia
}

Received November 16, 2017; Accepted 30 August 2018

Available online 31 August 2018

\begin{abstract}
The impacts of high dependence on oil on the economy have encouraged many countries to start eliminating or sharply reducing their dependence on oil consumption. As an oil importer as well as oil and gas producer country, Indonesia seeks to do the same thing by eliminating fuel subsidies, shifting to gas, and developing renewable energy. The oil price affects the economic and energy policies and impacts the efforts of reducing oil dependence.

Using an econometric model of Indonesia's energy that is constructed based on its energy balance model, this paper will examine factors that influence the oil demand in Indonesia. It will estimate the country's energy needs from 2017 to 2030 and simulate various alternative strategies to deal with oil dependencies, such as an increase in the refinery capacity, and a shift from oil to gas in the transportation sector.

This paper suggests that shifting from oil to gas in the transportation sector will be able to reduce oil dependency, while the alternative of increasing refinery capacity to 3 million barrel per day will be an opportunity to support greater short-term energy security and economic returns.
\end{abstract}

Keywords: Economy, econometric, energy, oil dependence, sustainable energy security

\section{Introduction}

The issue of oil has always been debated. While the world economy is highly dependent on oil, it is a limited non-renewable resource; and carbon emissions resulting from its use have a negative impact on the environment. Many efforts are being made by various countries to reduce the dependence on oil through diversification and conservation. European countries plan to become a carbon-free zone by boosting the use of non-fossil sources of power. The US encourages clean-coal technology, hydrogen, and biofuel. India plans to switch to gas and LNG imports and pursue nuclear power. China also plans to build more nuclear plants (Longmuir and Alhajj, 2007) in addition to expanding its investment in renewable energy and phasing out coal (Kejun and Woetzel, 2017). Nevertheless, the world projection of oil demand until 2040 is still high and dominated by transportation sector (Cordesman, 2015).

The effect of oil dependence and scenarios to reduce it vary between oil importing and exporting countries. They are influenced by various motivations, incentives, and political tension (Deniz, 2018). Cherfi and Kourbali (2012) explain four hypotheses in relation to energy consumption, economic growth, and strategies to reduce the dependency. First, the neutrality hypothesis states that there is no causality between economic growth and energy consumption. Under this hypothesis, the policies aimed at conserving energy resources fail to hinder economic growth (Asafu-Adjaye, 2000; Jumbe, 2004). Second, the feedback hypothesis states that there is a bidirectional causality running between economic growth and energy consumption. Energy consumption and economic growth are

\footnotetext{
* Corresponding author

E-mail address: dwi_atty@yahoo.com
}

C 2018 PYC. All right reserved. 
complementary, and the increase in energy consumption stimulates economic growth, and vice-versa. Third, conservation hypothesis determines the unidirectional causality running from economic growth to energy consumption. When causality runs from economic growth to energy consumption, an economy has less dependence on energy; thus energy conservation policies, such as phasing out energy subsidies, may not adversely affect economic growth (Mehrera, 2007). Fourth, the growth hypothesis evaluates the existence of the unidirectional causality running from energy consumption to economic growth (Narayan and Smyth, 2005; Ghosh, 2002). According to the growth hypothesis, a country's economy is energy dependent; in this case, the reduction of energy consumption will lead to a fall in economic growth because energy consumption is a prerequisite for economic growth (Ebohon, 1996).

The fluctuation of oil price compels economies to change their energy demand. For an oil importer, the increase in oil consumption and international oil price will affect the balance of trade, burden the currency depreciation (Restyani, 2012; Resosudarmo, 2002; Mishkin, 2001; Said et al., 2001), and cause higher cost of imports and lower value of exports, resulting in the decrease of real national income (Sukirno, 2011; Surjadi, 2006). The high cost of subsidy will burden the state budget (Sawitri, 2006), exacerbating fiscal balance (CSIS, 2011) and restricting the state budget for physical infrastructure development. The decline in oil price has an adverse impact on oil-exporting countries and a favorable impact on oil importers. For oil exporters, lower oil prices mean lower exports and lower revenue, and negatively impact its fiscal balance and economy. In contrast, oil importers get the benefits of lower energy cost via increased consumer spending, lower production costs for industries, and create an opportunity to reduce energy subsidies. There is a large number of papers examining how oil price affects the economy of oil exporter and/or importer countries, and what policies help to address the resulting consequences. Michelle Luk (2016) and Millington (2016) examine the effect of low oil price on oil-exporter countries, Albert and Gillet (2015) analyze both oil-exporter and importer countries.

As Indonesia is an oil importer as well as oil and gas producer country, oil plays two roles in its government finance: it is a source of revenue and an expense paying for fuel subsidy and crude oil imports. The fall in oil price since mid-2014 has had a multi-layered effect on Indonesia's economy. First, it created a momentum for reforming energy subsidies. Second, consumer spending increased in response to lower fuel cost, but it was also restrained by higher prices on imported goods and services due to the depreciation of the Indonesian rupiah. Second, the government collected less revenue from oil and gas sector, even though the spending on energy subsidies was reduced. Third, there has been an increase in investment in the non-resources sector as a result of reallocating energy subsidies to infrastructure. Fourth, investment and employment in the resources sector decreased, since oil price is commonly used by companies as a basis for approving and developing projects (Johnston, 2006). Fifth, cheaper oil price will make renewable energy sources such as solar and wind power less attractive. But Indonesia has set a target to have renewable energy provide $23 \%$ of total energy supply by 2025 . The target is to be achieved through attractive incentives and easily available permits for renewable energy development, removal of fuel subsidies, energy conservation measures, energy diversification (Indonesia’s Energy Outlook, 2016).

The high dependence on oil and the negative impact on the economy raise concerns about Indonesia's energy security sustainability and its economy in the future. The purpose of this study is to present economic impacts on Indonesia's energy demand and oil dependence. Using an econometric model of Indonesia's energy that is constructed based on its energy balance model, this paper will examine factors that influence oil demand across all sectors in Indonesia. The model will estimate Indonesia's energy needs up to 2030, starting in 2017 and based on data from 1990 until 2016. Finally, it will simulate two alternative strategies to deal with oil dependency: a shift from oil to natural gas in transportation sector and an increase in refinery capacity.

A shift from oil to gas was chosen due to transportation sector being the largest user of oil fuel worldwide (Cordesman, 2015). Some countries have introduced various alternative mechanisms to 
reduce oil consumption in transportation sector, such as (Fergusson et al, 2006): (1) the use of more fuel-efficient vehicles, by means of hybrid car technology development, (2) the use of alternative fuels for vehicles, e.g. biofuels and compressed natural gas (CNG), (3) more efficient use of fuel in transportation system with emphasis on public transportation and infrastructure, and (4) using fewer vehicles to reduce the amount of fuel needed. In Indonesia, some efforts have been made to replace oil fuel with biofuel, natural gas in several big cities, electricity for electric trains, introduction of more buses and trains, and improvements in transportation infrastructure, especially in Jakarta. However, the impact of these measures remains low. Considering that Indonesia's gas reserves in 2015 were 150.4 trillion cubic feet (TCF), including 101.54 TCF of proven reserves and 48.85 TCF of potential reserves, and half of its production is used for exports, the use of natural gas for transportation sector should be maximized to reduce dependence on oil. Substituting oil fuel with CNG is a commonly used program in countries like Iran, Thailand, Pakistan, Bangladesh, and China.

The addition of refinery capacity was chosen as an alternative strategy to accommodate government regulation No.79/2014 on national energy policy related to operational reserves. According to the regulation, Indonesia's fuel stock is corresponding to less than 25 days' worth of domestic consumption. Therefore, Indonesia should pay more attention to the refining sector as an important component in achieving energy security by ensuring the total energy demand for petroleum fuels is met from domestic and import supplies. Indonesia should consider India's experience, which has been struggling to increase its domestic crude oil production and is positioning itself as a major refining hub. In 1985, Indonesia and India had the same refinery capacity of 867 thousand barrels per day (BPD). However, Indian refinery industry has expanded much faster to reach the current capacity of 5.3 million BPD, while Indonesia's utilized capacity is currently at 885 thousand BPD of total 1.16 million BPD. Indonesia's oil demand in 2016 was 1.6 million BPD with the difference between the refinery capability and the need being only $55 \%$.

\section{Methodology}

This study developed Atty et al.'s (2013) previous study by adding research period data, from 1990 to 2016, and introducing some policy changes into the model. The research was conducted in four stages:

1. Building the energy balance model. Indonesia's energy model in figure 1 is constructed by modifying IEA's world energy model. Non-fossil energy sources (i.e., hydropower, geothermal, and biomass) were included into the model that reconciles the flow of energy supply, transformation, and the final demand which is disaggregated per sector of energy user and type of energy. In addition, policy changes variables are also included into the model, such as revocation of subsidies in 2015, changes in PSC sharing split on oil production forecast, etc. A total of 79 variables were included in 48 equations, consisting of 26 behavioral equations and 22 identities, as shown in table 3 .

2. Solving the model using simultaneous econometric approach by employing two-stage least squares (2SLS) regression analysis. In this section, the relationship and correlation among different variables in the economy, energy, and policy were tested.

3. Validating the estimated simultaneous equation by generating an ex-post forecast (Greene, 2008) for the period of 2010 to 2016 to determine the model's ability to predict the variable. The forecast will be evaluated in terms of the accuracy and the ability to predict data changes by using the root mean square percentage error (RMSPE) and U-Theil's (measure of forecasting quality) tests. A lower RMSPE and U-Theil's indicate better performance in predicting turning points in the data.

4. Forecasting the baseline energy demand and simulating various alternative strategies to deal with oil dependency by changing the value of exogenous variables. Alternative strategies include an increase in refining capacity and optimization of the energy diversification in the transportation sector by switching from oil to gas. Building a baseline model assumption includes population growth, economic growth, energy price, policy and regulation change. The annual population rate is assumed to fall $0.6 \%$ until 2030 ; the growth trend continues to decline due to increasing public 
awareness of prosperous, healthy and educated family. Considering declining economic growth in the last five years due to slowing global economic growth and current economic conditions, it is assumed that GDP will grow at an average of 5.4\% per year until 2030. The energy price assumption is based on Southeast Asia Outlook by the International Energy Agency (IEA) from 2015; price increase of $1.2 \%$ per year for coal, $0.9 \%$ for gas, and $2.3 \%$ for fuel.

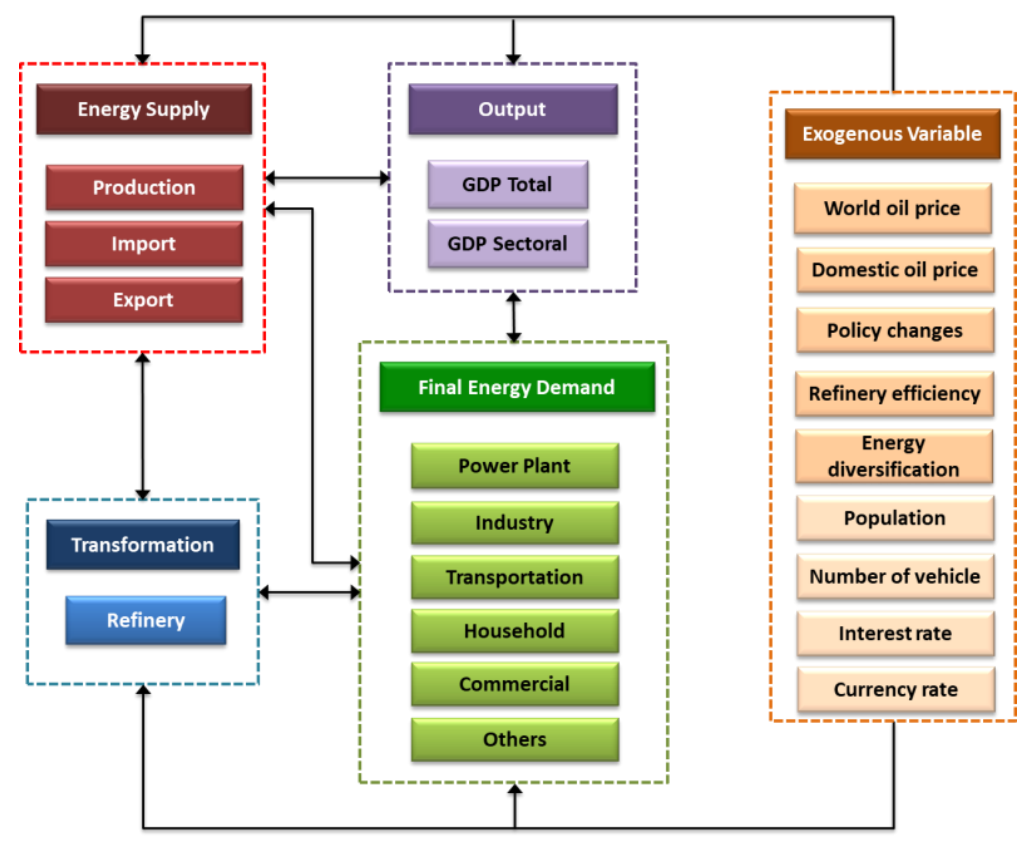

Figure 1. The energy balance model scheme

\section{Results and Discussion}

\subsection{Model Estimation}

The estimation results from econometric modeling of energy balance for Indonesia's oil demand in all economic sectors for the period of 1990 to 2016 are shown in table 1. It is concluded that domestic fuel price has a negative effect on oil demand in all sectors except power generation. This is because it is not easy to change the energy source due to price change, and the sector is still getting subsidies from the government. The declining world oil price since mid-2014, indirectly affected the oil fuel and energy demand because at the same time the government also revokes fuel and energy subsidies. In 2015-2016, domestic gasoline price decreased but its consumption slightly declined due to the slowing of Indonesian economy. The income affects the oil demand in the form of sectoral GDP and GDP per capita that has a significant correlation and positive effect on oil demand. The household sector is the only exception because people are already switching to subsidized LPG and obtaining Kerosene is difficult. The effect of natural gas switching program on oil demand is seen in several variables such as the ratio of fuel and gas demand, gas demand in the sector, and gas prices.

Table 1. The 2SLS estimation result of sectoral energy demand

\begin{tabular}{|c|c|c|c|c|c|c|}
\hline $\begin{array}{c}\text { Endogenous } \\
\text { Variable }\end{array}$ & $\begin{array}{c}\text { Exogenous } \\
\text { Variable }\end{array}$ & Coefficient & Std. Error & t-Statistic & Probability & $\overline{\mathbf{R}^{2}}$ \\
\hline \multirow{2}{*}{$\begin{array}{l}\text { Oil demand in } \\
\text { commercial } \\
\text { sector, }\end{array}$} & $\mathrm{C}$ & -12725.7700 & 3518.8170 & -3.6165 & 0.0003 & 0.9103 \\
\hline & GDP & 18867.1300 & 4393.2110 & 4.2946 & 0.0000 & \\
\hline
\end{tabular}




\begin{tabular}{|c|c|c|c|c|c|c|}
\hline $\begin{array}{c}\text { Endogenous } \\
\text { Variable }\end{array}$ & $\begin{array}{c}\text { Exogenous } \\
\text { Variable }\end{array}$ & Coefficient & Std. Error & t-Statistic & Probability & $\overline{\mathbf{R}^{2}}$ \\
\hline COMOLT & $\begin{array}{l}\text { Ratio oil to gas in } \\
\text { commercial }\end{array}$ & 0.4667 & 0.1259 & 3.7070 & 0.0002 & \multirow{5}{*}{0.9172} \\
\hline \multirow{4}{*}{$\begin{array}{l}\text { Oil demand in } \\
\text { power generation } \\
\text { sector, EGOLT }\end{array}$} & COMOLT(-1) & 0.0006 & 0.0005 & 1.2497 & 0.0920 & \\
\hline & $\mathrm{C}$ & -192221.6000 & 43586.2600 & -4.4101 & 0.0000 & \\
\hline & Diesel price & 0.0031 & 0.0123 & 0.2503 & 0.0802 & \\
\hline & $\begin{array}{l}\text { Gas demand in } \\
\text { power generation } \\
\text { sector }\end{array}$ & -0.6974 & 0.1534 & -4.5449 & 0.0000 & \\
\hline \multirow{4}{*}{$\begin{array}{l}\text { Oil demand in } \\
\text { industrial sector, } \\
\text { IDOLT }\end{array}$} & Population & 1.2425 & 0.2395 & 5.1873 & 0.0000 & \multirow{4}{*}{0.8534} \\
\hline & $\mathrm{C}$ & 16420.5300 & 9515.9690 & 1.7256 & 0.0851 & \\
\hline & Diesel price & -0.0195 & 0.0131 & -1.4909 & 0.0367 & \\
\hline & $\begin{array}{l}\text { Gas demand in } \\
\text { industrial sector }\end{array}$ & 0.1485 & 0.1010 & 1.4704 & 0.0421 & \\
\hline \multirow{6}{*}{$\begin{array}{l}\text { Oil demand in } \\
\text { transportation } \\
\text { sector, TROLT }\end{array}$} & $\begin{array}{l}\text { GDP industrial } \\
\text { sector }\end{array}$ & 0.0093 & 0.0412 & 0.2253 & 0.0218 & \multirow{6}{*}{0.9909} \\
\hline & $\operatorname{IDOLT}(-1)$ & 0.7005 & 0.1249 & 5.6081 & 0.0000 & \\
\hline & $\mathrm{C}$ & 14544.81 & 15873.18 & 0.9163 & 0.0027 & \\
\hline & Gasoline price & -0.1079 & 0.01338 & -8.0649 & 0.3600 & \\
\hline & LGV price & 0.2271 & 0.03047 & 7.4551 & 0.0000 & \\
\hline & GDP/capita & 9686.9670 & 2796.9350 & 3.4634 & 0.0006 & \\
\hline \multirow{4}{*}{$\begin{array}{l}\text { Oil demand in } \\
\text { residential sector, } \\
\text { REOLT }\end{array}$} & $\begin{array}{l}\text { Number of } \\
\text { vehicle }\end{array}$ & 2.1995 & 0.2203 & 9.9842 & 0.0000 & \multirow{4}{*}{0.8529} \\
\hline & $\mathrm{C}$ & -265602.0000 & 82903.6700 & -3.2037 & 0.0015 & \\
\hline & LPG price & -0.0757 & 0.0215 & -3.5157 & 0.0005 & \\
\hline & Ratio oil to gas & 203334.8000 & 70114.8800 & 2.9000 & 0.0039 & \\
\hline \multirow{6}{*}{$\begin{array}{l}\text { Oil demand in } \\
\text { other sector, } \\
\text { OCOLT }\end{array}$} & $\begin{array}{l}\text { Number of } \\
\text { household }\end{array}$ & 4.2145 & 0.5332 & 7.9048 & 0.0000 & \multirow{6}{*}{0.8774} \\
\hline & GDP/capita & -4539.7100 & 3684.5450 & -1.2321 & 0.0186 & \\
\hline & $\mathrm{C}$ & 6541.1930 & 5203.6090 & 1.2570 & 0.0094 & \\
\hline & Diesel price & -0.0025 & 0.0022 & -1.1658 & 0.0443 & \\
\hline & GDP other sector & 0.0091 & 0.0086 & 1.0621 & 0.0887 & \\
\hline & OCOLT(-1) & 0.6015 & 0.1474 & 4.0814 & 0.0001 & \\
\hline
\end{tabular}

\subsection{Model Validation}

The models which are built based on a historical period from 1990 to 2009 are validated by withholding six years of data (2010-2016) when specifying and estimating the model. This process 
generates an ex-post forecast to determine how well the models predicted the endogenous variables. Table 4 presents the validation result of the energy balance model, illustrating the validation indicators in 26 structural equations in the model, and suggests that the estimated model is good enough to provide an accurate estimation value. The analysis based on RMSPE shows that 24 out of 26 structural equations in the model have smaller RMSPE values of $20 \%$ with an average deviation of $7.4 \%$. The smaller forecast error value indicates the model's reliability to make a prediction. The UTheil's test shows that all structural equations in the model have values smaller than 0.15 , indicating that the model can be used for the better forecasting simulation analysis. The small value of bias proportion (UB) below 0.2 indicates nonsystematic bias resulting from all equations, except the equation of GDP in the commercial sector (COMPt) which has a UB value above 0.2. However, higher determination coefficient value (R-square) of COMPt (97.1\%) indicates that all exogenous variables have been able to explain the GDP in the commercial sector, so the revision of the equation will not be necessary. The small value of variance proportion (UV) below 0.3 indicates that the models have been able to replicate the fluctuation pattern of the actual series. Finally, the higher value of covariance proportion (UC) close to 1 indicates that the model is ideal for forecasting.

\subsection{Forecast and Simulations}

Currently, the share of Indonesia's oil reserves is only $0.2 \%$ of the total world oil reserves. Indonesia's oil production declined $4.3 \%$ in the last five years due to mature oil production wells and limited new production wells. At the beginning of 2017, the Indonesian government introduced PSC gross split under Ministry of Energy and Mineral Resource (MoEMR) law No. 08/2017 which changed the upstream fiscal terms to create a flexible PSC in order to account for uncertainties in field size, reservoir condition, oil price, production, economics, etc. This change is important for the government to encourage PSC operators to streamline and operate more effectively and efficiently. It will also increase state revenues by eliminating the cost recovery system and removing the need for related project budget scrutiny by the regulator. The regulation was then revised into MoEMR No.52/2017 to provide more economic benefits to the PSC contractors. It is assumed that the implementation of the new regulation will slow the production decline by $2.2 \%$ until 2030 .

The drop in oil prices since mid-2014 followed by the world economic slowdown has had an impact on the slowing economic growth and energy consumption in Indonesia in the last two years. To support the average economic growth of $5.4 \%$ per year, it is estimated that energy demand needs to increase by $4.3 \%$ per year, or from 1,648 million barrels oil equivalent (BOE) in 2016 to 3,221 million BOE in 2030, as shown in figure 2. The lower rate of energy demand growth compared to GDP is due to the currently occurring shift where the commercial sector is the largest GDP producer (6.9\% growth), and it consumes less energy.

In the 2030 energy mix, oil share is predicted to decline from $33 \%$ to $30 \%$, and its position as the leading energy source is slightly changed by gas $(17 \%)$ and coal $(26 \%)$. Electricity share increases from $8 \%$ to $11 \%$ as the shift in lifestyle takes place along with the economic improvement and technology development. The increase in renewable's share is predicted to remain small under the 'business as usual' scenario, where their development is still constrained by bureaucratic licensing, investment and price. 


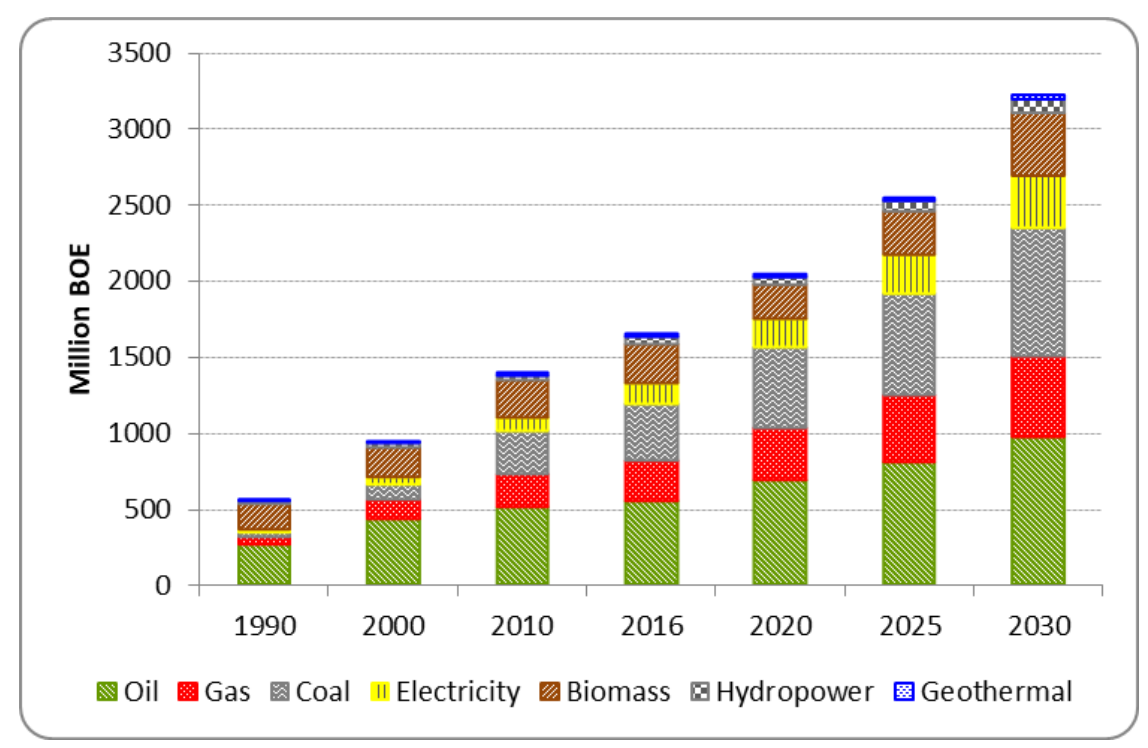

Figure 2. Chart of Indonesia's energy demand

Transportation still dominates oil use in Indonesia with a share of $79 \%$ in 2030 (figure 3) and grows $5.5 \%$ per year from 922 thousand BPD in 2016 to 2.2 million BPD in 2030 along with the increase of GDP per capita and a number of private vehicles. On the contrary, fuel consumption in other sectors (residential, industry, commercial, power generation, and others) decreases. Oil demand for electricity generation declines to $4 \%$ per year as well as oil demand for the commercial sector, which falls by $5.6 \%$ per year until 2030. In the household sector, Kerosene is fully replaced with LPG and city gas by 2021 .

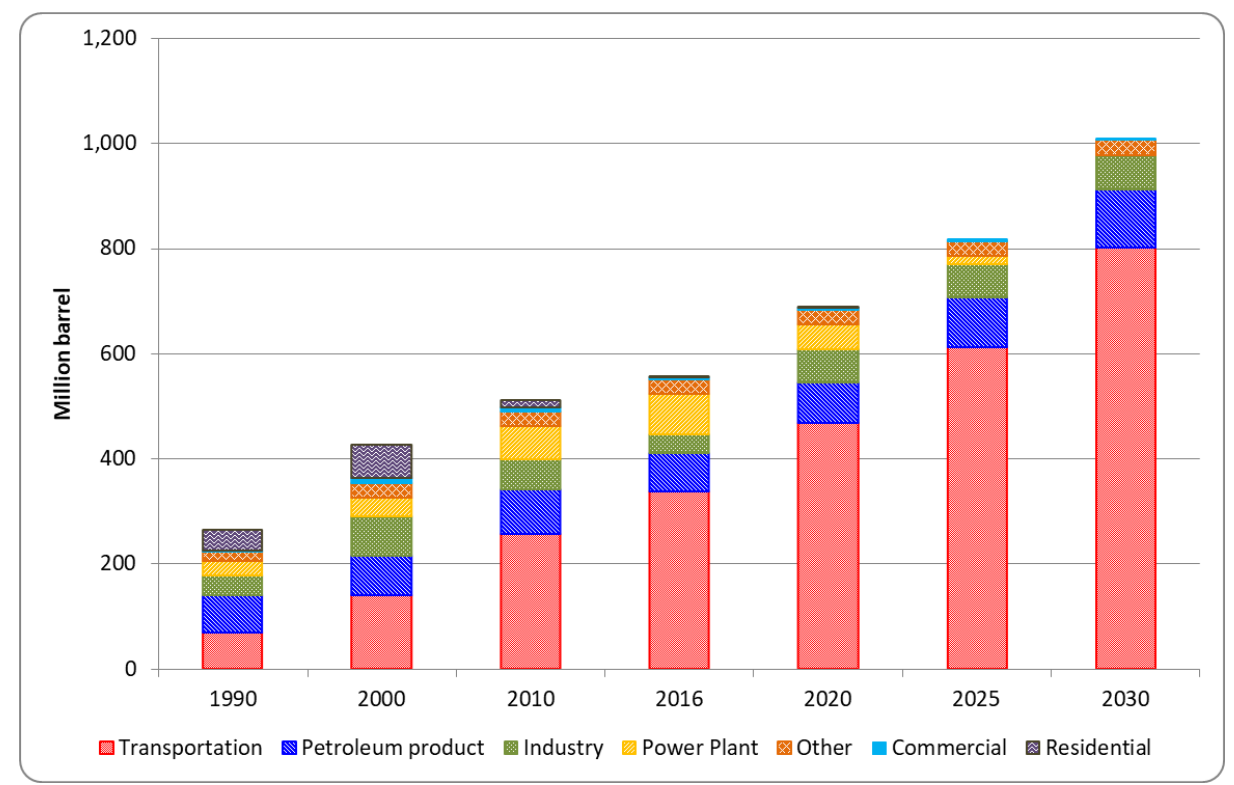

Figure 3. Indonesia Oil Demand 1990-2030

The number of vehicles is predicted to grow $5.6 \%$ per year. In Indonesia, car ownership is a symbol of prestige, and its ownership is associated with rising income and people's ability to afford higher-end private transportation. Furthermore, estimation results show that if it is assumed that oil price range is in $\$ 60-80$ /barrel up to 2030 , the government's efforts to build mass transportation facilities will fail to significantly reduce fuel consumption, given that taxi transportation is expected to continue to grow. 
Without active energy diversification, the share of oil fuel in transportation sector will remain large, at $96 \%$, while the rest of $3 \%$ and $1 \%$ will come from biodiesel and natural gas respectively. According to the simulation that examines intensive $\mathrm{CNG}$ conversion program until 2030 designed to gradually convert $10 \%$ of total vehicles, especially for public transportation (i.e., buses, taxies, and government vehicles). The fuel consumed by different transportation modes and activities may vary. Applying energy intensity in transportation sector from Sugiyono (2013) to the calculation, this program is projected to convert about 8 million vehicles in 2030 that would reduce consumption of total oil fuel demand in transportation sector by $9 \%$, a decrease of about 205 thousand BPD of total 2.2 million BPD.

In addition to the necessary supply of gas, the availability of CNG fueling stations is also required. This scenario assumes that one CNG fueling station will serve 5,000 cars and buses. The simulation estimates that the government should add more than 63 gas stations in 2018 and increase this number to 1,600 gas stations in 2030. Therefore, the government is advised to immediately prepare a longterm plan of integrated and available gas infrastructure, such as fuel storage, pipelines, LNG receiving terminal units, mini LNG, and CNG carriers for delivery and distribution to fueling stations from gas sources in remote areas. Thus, real-sector economy will grow, create jobs, and reduce oil dependency.

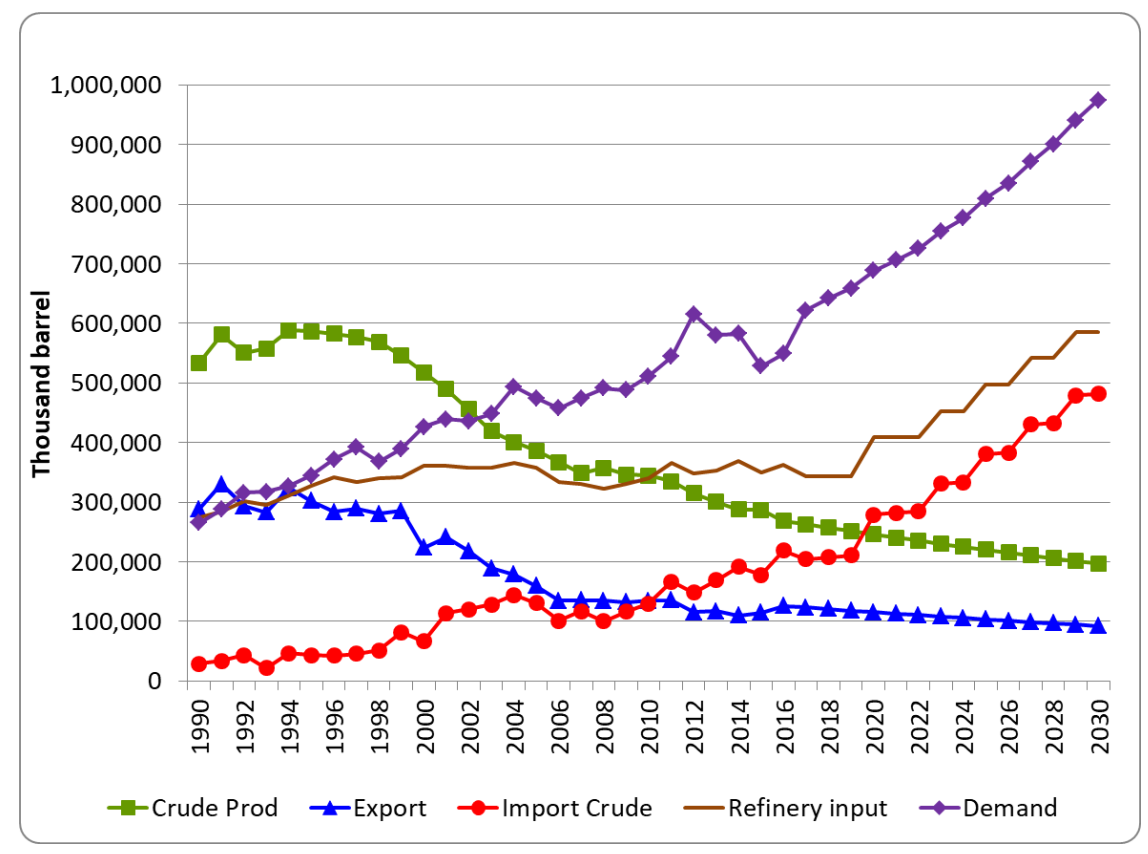

Figure 4. Crude oil and fuel supply and demand

The study also points out that although oil share is expected to decrease, the demand for fuel until 2030 continues to increase due to economic and population growth. At the same time, refinery capacity remains the same until 2019 causing an increase in both crude and fuel imports. Starting in the next three years, as shown in figure 4, additional refinery capacity is expected to reach 2 million BPD or 727 million barrels in 2030. Thus, increasing imports of both crude and fuel will contribute to meet the national fuel demand of 2.2 million BPD. The import dependency ratio will increase from $41 \%$ in 2016 for crude oil and $24 \%$ for fuel to $82 \%$ and $43 \%$ respectively for crude oil and fuel in 2030. This indicates that Indonesia is beginning to experience in high dependency on the crude oil supply from abroad, which greatly affects its national energy security.

Alternatively, by increasing the refinery capacity, Indonesia would reduce its dependence on the imported fuel and petroleum products by 2028. The expansion of crude oil refinery capacity to 3 million BPD (1,095 million barrels) would mean a 50\% increase on the baseline, even though $90 \%$ of the crude or 2.7 million BPD would be obtained from imports in 2030. The simulation on table 2 estimates total import value from both fuel and crude import for this scenario in 2030 is $72,883 \mathrm{MM} \$$ 
or $11 \%$ lower than its baseline $81,975 \mathrm{MM} \$$. The value added from refining sector and the export of fuel and petroleum products also estimate to increase by more than $20 \%$, which are economically beneficial. Thus, the addition of this refinery capacity calls for government action to immediately build crude oil storage facilities for refinery input as well as for strategic crude oil storage.

Table 2. Import estimation in 2030

\begin{tabular}{lcc}
\hline \multicolumn{1}{c}{ Variable } & Baseline & $\begin{array}{c}\text { Case 2. Increase } \\
\text { Refinery capacity }\end{array}$ \\
\hline Crude import, Mbbls & 481,709 & 990,631 \\
Fuel import, Mbbls & 420,596 & - \\
Total oil import in value, MM\$ & 81,975 & 72,883 \\
\hline
\end{tabular}

To accommodate the increasing demand for electricity, in 2015, Indonesia set a target of $136 \mathrm{GW}$ of power capacity by 2025 and $430 \mathrm{GW}$ by 2050 , compared with the current capacity of $55.5 \mathrm{GW}$. Based on the General Plan for National Electricity Development (RUKN), 80.5 GW of capacity will be added over the period of 2016-2025, dominated by coal (43\% of total additional capacity), followed by natural gas $(29 \%)$, hydro $(18 \%)$, and geothermal $(8 \%)$. This program is very ambitious considering that the additional capacity represents double Indonesia's installed power capacity. The emerging market of new power users is needed, including an expanding industrial sector, household sector switch to the electricity-based home appliances, and transportation sector developing the use of an electric vehicle. Delayed experiences of similar programs in 2005-2014 demonstrate that there are some challenges that need to be addressed. These include licensing, and land acquisition issues, lack of financing, delays in government-backed loans, grid infrastructure constraints, construction setbacks, and various technical difficulties (Cornot-Gandolphe, 2017). Therefore, excess capacity delays in achieving program targets are likely.

To support the additional $80.5 \mathrm{GW}$ of power capacity supply that is expected to be on-stream in 2030 or an increase of $5.4 \mathrm{GW}$ per year, the coal exports are expected to decline in the future, from $77 \%$ in the last five years to $66 \%$ in 2030 due to rising domestic demand.

\section{Conclusion}

Indonesia's energy demand is expected to double by 2030, from 1,648 million barrel oil equivalent (boe BOE) in 2016 to 3,221 million BOE in 2030. Coal and gas will replace oil fuel in the energy mix to meet the needs of power generation, industrial, and transportation sectors. There will also be an increase in electricity demand.

The average growth of oil demand by $3.5 \%$ per year has implications for Indonesia's dependency on both crude oil and oil product. This paper shows that shifting from oil to gas in the transportation sector will be able to reduce oil dependency, while the alternative of increasing refinery capacity to 3 million BPD will be an opportunity to support greater short-term energy security and economic returns.

A number of benefits derived from diversification program in transportation sector have implications in formulating integrated policy in energy sector and the automotive industry, some of which are ensuring the availability of gas supply and infrastructure, conversion facilities, and sufficient number of gas stations that would ease people to switch to natural gas vehicles (NGVs).

Future research is required to discuss the obstacles in the implementation of strategies to reduce oil dependency, and the long-term impact of additional refinery capacity on the environment, economy and crude supply. 


\section{References}

Albert, M., Gillet, T. (2015). Impact of falling oil price on the major emerging economies. Tresor Economics (No. 157, pp.8).

Asafu-Adjaye, John. (2000). The relationship between energy consumption, energy price and economic growth: Time series evidence from Asian developing countries. Energy Economic Journal (Vol. 22, pp.615-625).

Atty, D. M., Zulkifli, M., Hamzah, M. Z., \& Trijana, R. S. (2013). Economy growth and oil import requirement in Indonesia. Journal of Energy Technologies and Policy (Vol.3, No.11, pp.76-84).

Cherfi, S. E., and Kourbali, B. (2012). Energy consumption and economic growth in Algeria: Cointegration and causality analysis. International Journal of Energy Economics and Policy (Vol.2, No.4, pp.238-249).

Cordesman, A. H. (2015). American strategy and critical challenges in U.S.: Energy import dependence. Center for Strategic \& International Studies. Retrieved from https://csisprod.s3.amazonaws.com/s3fs-public/legacy_files/files/publication/150504_energy_strategy.pdf.

Cornot-Gandolphe, S. (2017). Indonesia's electricity demand and the coal sector: Export or meet domestic demand? Retrieved from https://www.oxfordenergy.org/wpcms/wpcontent/uploads/2017/03/Indonesias-Electricity-Demand-and-the-Coal-Sector-Export-or-meetdomestic-demand-CL-5.pdf.

Centre for Strategic and International Studies (CSIS). (2011). Penyesuaian subsidi BBM pilihan rasional penyelamatan ekonomi. Naskah Kebijakan.

Deniz, P. (2018). Oil price and renewable energy: Oil dependent countries. Retrieved from https://editorialexpress.com/cgi-bin/conference/download.cgi?db_name=MEEA18\&paper_id=49.

Ebohon, O.J. (1996). Energy, economic growth and causality in developing countries: A case study of Tanzania and Nigeria. Energy Policy (Vol.24, pp.447-453).

Ferguson, M., Mackay, E., \& Skinner, I. (2006). Over a barrel: Reducing the UK and Europe's oil dependency. London.

Ghosh, S. (2002). Electricity consumption and economic growth in India. Energy Policy (Vol.30, pp.125-129).

Greene, W. H. (2008). Econometric analysis. Sixth Edition. Upper Saddle River. NJ: Prentice Hall

Jumbe, Charles, B. L. (2004). Cointegration and causality between electricity consumption and GDP: empirical evidence from Malawi. Energy Economics (Vol.26, No.1, pp.61-68).

Johnston, D. (2006). How To Evaluate the fiscal terms of oil contracts. Retrieved from http://policydialogue.org/files/publications/Ch03.pdf

Kejun, J., Woetzel. J. (2017). China's renewable energy revolution. Retrieved from https://www.project-syndicate.org/commentary/china-renewable-energy-revolution-by-jiangkejun-and-jonathan-woetzel-2017-08?barrier=accessreg

Longmuir, G., Alhajj, A. F. (2007). Reducing oil dependence without triggering a global crisis. Middle-East Economic Survey (Vol. XLIX. No.9).

Luk, M. (2016). How oil-exporting countries navigate low price environments. IEEJ

Mahrera, Mohsen. (2007). Energy-GDP relationship for oil-exporting countries: Iran, Kuwait and Saudi Arabia, Organization of the Petroleum Exporting Countries (OPEC) Review

Millington, D. (2016). Low crude oil prices and their impact on the Canadian economy. Retrieved from http://resources.ceri.ca/PDF/Pubs/Studies/Study_156_Full_Report.pdf

Ministry of Energy and Mineral Resource. (2016). Indonesia energy outlook 2016. Retrieved from https://www.esdm.go.id/assets/media/content/outlook_energi_indonesia_2016_opt.pdf

Mishkin, Frederick, S. (2001). The economics of money, banking and financial market. Sixth Edition. Columbia: Columbia University.

Narayan, P. K., Smyth, R. (2005). Electricity consumption, employment, and real income in Australia: evidence from multivariate Granger causality tests. Energy Policy (Vol.33, No.11, pp.09-16).

Restyani, D. (2012). Pengaruh fluktuasi harga minyak dunia, inflasi dan suku bunga bank umum terhadap PDB di Indonesia periode 1999-2009. Tesis. Universitas Hasanudin.

Resosudarmo, B. P. (2002). Indonesia's clear air program. BIES (Vol.38, No.3, pp.343-65). 
Said, U., Ginting, E., Horridge, M., Utami, N. S., Sutijastoto, \& Purwoto, H. (2001). Kajian dampak ekonomi kenaikan BBM. Final report USAID in collaboration with Ministry of Energy and Mineral Resource.

Sawitri, H. H. (2006). Dampak defisit anggaran terhadap pertumbuhan ekonomi. Jurnal Organisasi dan Manajemen (Vol.2, No.1, pp.1-10).

Sugiyono. (2013). Data historis konsumsi energi dan proyeksi permintaan penyediaan energi di sektor transportasi. Prosiding Seminar dan Peluncuran Buku Outlook Energi Indonesia 2012. BPPT. Jakarta

Sukirno, S. (2011). Makroekonomi: Teori pengantar. Third Edition. Rajawali Pers. Jakarta

Surjadi, A. J. (2006). Masalah dampak tingginya harga minyak terhadap perekonomian. Presented on half day workshop "Antisipasi dampak negatif tingginya harga minyak dunia terhadap stabilitas perekonomian nasional”. Ministry of Finance. 
Appendix A

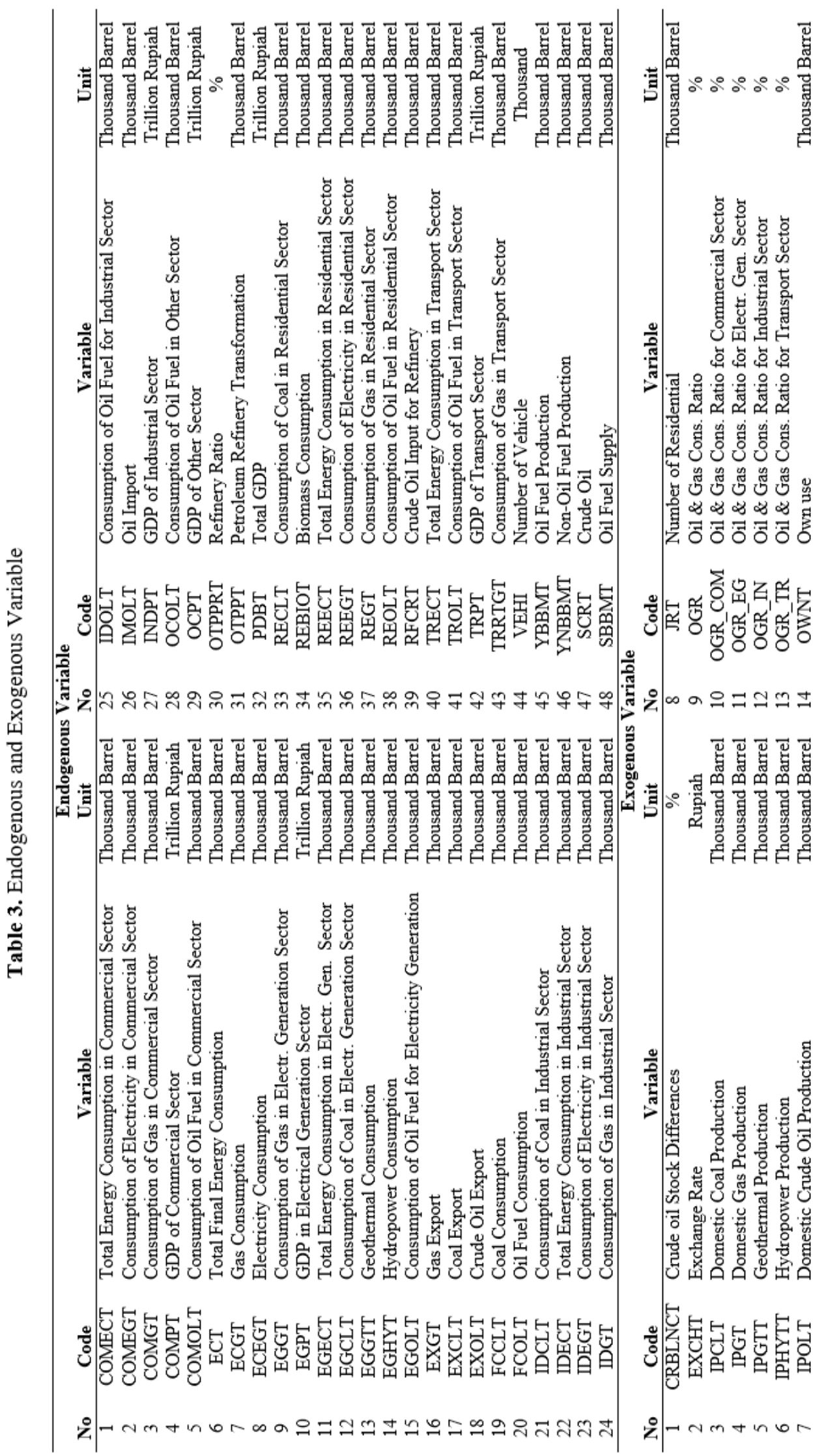



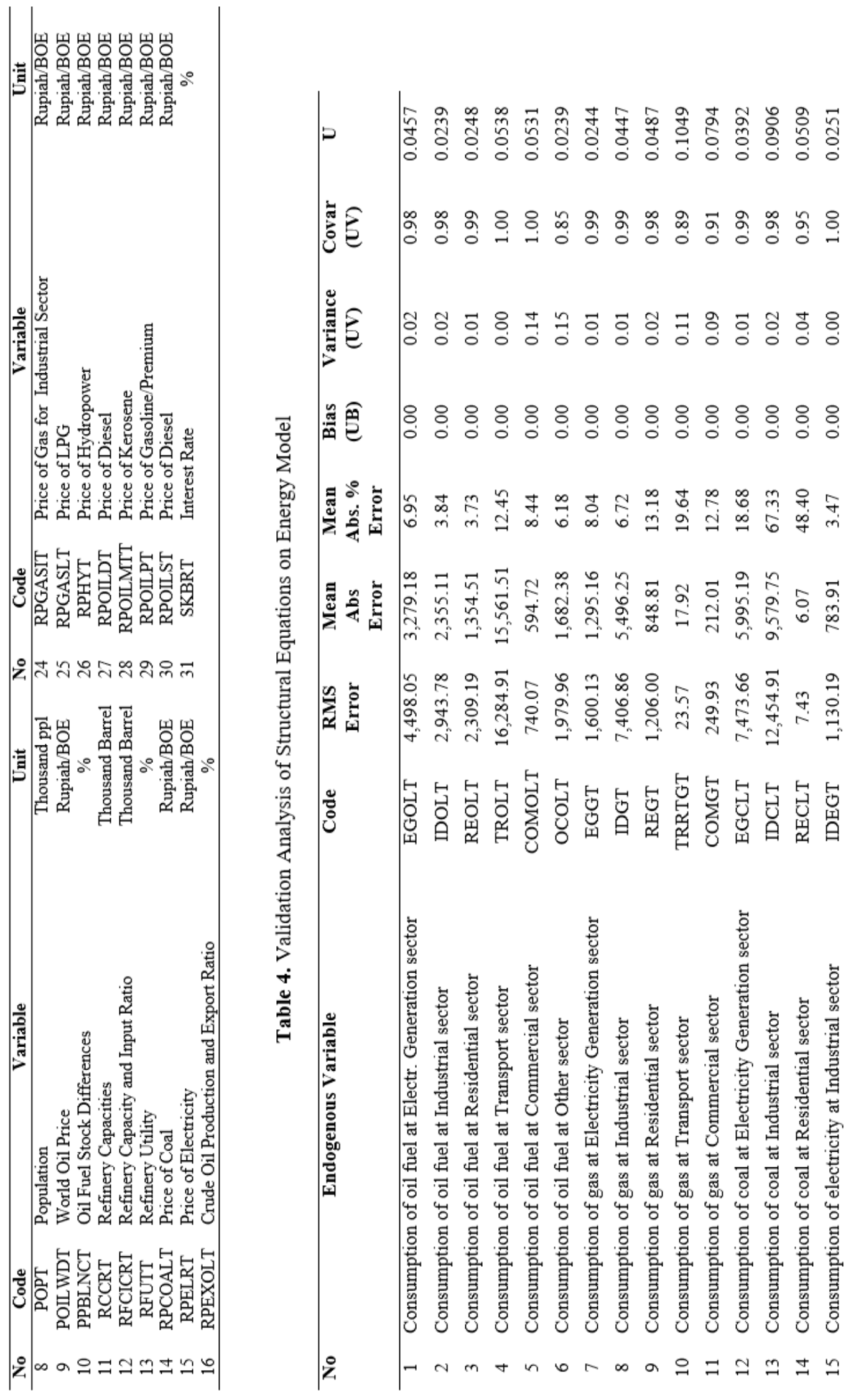


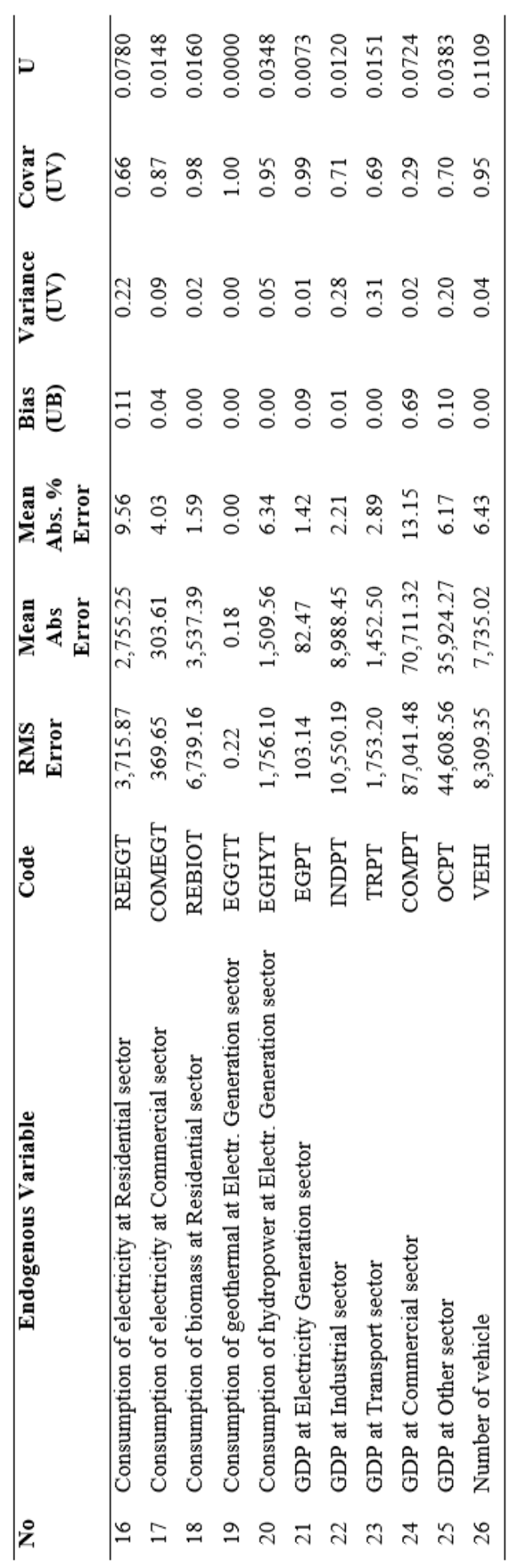

